\title{
Impact of monovalent cations on soil structure. Part I. Results of an Iranian soil
}

\author{
Elham Farahani ${ }^{1}$, Hojat Emami ${ }^{1 *}$, Thomas Keller ${ }^{2,3}$, Amir Fotovat $^{1}$, and Reza Khorassani ${ }^{1}$ \\ ${ }^{1}$ Faculty of Agriculture, Department of Soil Science, Ferdowsi University of Mashhad, Azadi Square, Mashhad, 917751163 Iran \\ ${ }^{2}$ Agroscope, Department of Agroecology and Environment, Zurich, Reckenholzstrasse 191, CH-8046, Switzerland \\ ${ }^{3}$ Department of Soil and Environment, Swedish University of Agricultural Sciences, Box 7014, SE-75007 Uppsala, Sweden
}

Received July 21, 2017; accepted December 11, 2017

\begin{abstract}
This study investigated the impact of monovalent cations on clay dispersion, aggregate stability, soil pore size distribution, and saturated hydraulic conductivity on agricultural soil in Iran. The soil was incubated with treatment solutions containing different concentrations $\left(0-54.4 \mathrm{mmol} \mathrm{l}^{-1}\right)$ of potassium and sodium cations. The treatment solutions included two levels of electrical conductivity $\left(\mathrm{EC}=3\right.$ or $\left.6 \mathrm{dS} \mathrm{m}^{-1}\right)$ and six $\mathrm{K}: \mathrm{Na}$ ratios per electrical conductivity level. At both electrical conductivity levels, spontaneously dispersible clay increased with increasing $\mathrm{K}$ concentration, and with increasing $\mathrm{K}: \mathrm{Na}$ ratio. A negative linear relationship between percentage of water-stable aggregates and spontaneously dispersible clay was observed. Clay dispersion generally reduced the mean pore size, presumably due to clogging of pores, resulting in increased water retention. At both electrical conductivity levels, hydraulic conductivity increased with increasing exchangeable potassium percentage at low exchangeable potassium percentage values, but decreased with further increases in exchangeable potassium percentage at higher exchangeable potassium percentage. This is in agreement with earlier studies, but seems in conflict with our data showing increasing spontaneously dispersible clay with increasing exchangeable potassium percentage. Our findings show that clay dispersion increased with increasing $\mathrm{K}$ concentration and increasing $\mathrm{K}: \mathrm{Na}$ ratio, demonstrating that $\mathrm{K}$ can have negative impacts on soil structure.

Keyw ords: aggregate stability, dispersible clay, potassium, soil pore size, water retention
\end{abstract}

\section{INTRODUCTION}

Soil structure controls many important soil functions and processes, such as water infiltration, soil aeration, rootability and workability (Kay, 1990). Clay particles and their associations with mineral and organic soil components are important in maintaining soil structure and

\footnotetext{
*Corresponding author e-mail: hemami@um.ac.ir
}

for sustaining favourable soil conditions in agricultural soils. Salts with either natural or anthropogenic origin are known to have negative impacts on soil structure and hence soil quality. This is because monovalent cations such as sodium $(\mathrm{Na})$ or potassium $(\mathrm{K})$ can create clay dispersion and swelling that result in the degradation of soil structure (Rengasamy et al., 2016). Swelling occurs when the monovalent cation concentration is high (for instance, exchangeable sodium percentage (ESP) higher than 15) in soil containing expansive clays, while dispersion occurs at low cation concentrations (ESP lower than 15) (Shainberg and Letey, 1984; Sumner, 1993). Swelling and dispersion can reduce soil porosity, thus reducing the water and air transport capability of soils and potentially increasing soil erodibility (Shainberg and Letey, 1984; Sumner, 1993).

Most investigations on clay dispersion have concentrated on the effect of highly exchangeable $\mathrm{Na}$ on soil structure and stability (Rengasamy, 2002). Only a few studies have shown that $\mathrm{K}$, which is an important plant nutrient, can also affect soil structure even when the exchangeable $\mathrm{Na}$ concentration is small (Arienzo et al., 2009; Emami et al., 2014; Rengasamy, 2006; Smiles, 2006). Exchangeable K may create effects on soil structure similar to $\mathrm{Na}$, but it has received less attention because amounts of $\mathrm{K}$ are typically low in salt-affected soils (Rengasamy and Marchuk, 2011).

The application or inclusion of monovalent cations can jeopardize both the geometrical arrangement of soil constituents and soil pores (structural form) and the structural stability. Soil aggregate stability is an important soil characteristic influencing soil functioning and crop production. Arshad and Coen (1992) suggested soil aggregate

(C) 2018 Institute of Agrophysics, Polish Academy of Sciences 
stability as a physical property of soil that can be considered an indicator of soil quality. Soil aggregates affect water flow in soil, aeration, microbial activity, nutrient cycling, run-off and erosion and root development (Six et al., 2004). The stability of macro-aggregates $(>250 \mu \mathrm{m})$ is usually measured in 'aggregate stability tests', whereas micro-aggregate $(<250 \mu \mathrm{m})$ stability is normally measured in 'ispersion tests'. However, the characterisation of soil aggregation requires an assessment of both macro- and micro-aggregate stability. For example, macro-aggregates play an important role in soil organic carbon stabilisation, while soil organic matter protection is linked to microaggregates (Six et al., 2004). Barzegar et al. (1994) and Levy and Torrento (1995) observed a detrimental effect of $\mathrm{Na}$ on macro-aggregate stability, and that sodicity reduced the amount of macro-aggregates with an associated increase in the amount of micro-aggregates. Data on K are scarce, but Quirk and Schofield (1955) found that K was as destructive as Na, and Levy and Torrento (1995) reported that K was deleterious and reduced macro-aggregate stability.

Soil properties such as air capacity, plant available water and relative field capacity directly depend on the soil pore size distribution (Dexter, 2004), while structural stability is indirectly affected (Pieri, 1992). Monovalent cation-induced clay dispersion and breakdown of aggregates can result in the blocking (clogging) of pores (Arienzo et al., 2009), potentially causing a shift towards smaller pores and creating impermeable layers (Chen et al., 1983), and thereby reducing soil fluid transport capability. Similarly, swelling reduces soil pore sizes, yielding to a decrease in permeability (Chaudhari and Somawanshi, 2004). Khan and Afzal (1990) found that the saturated hydraulic conductivity $\left(K_{s}\right)$ is affected by the amount of exchangeable $\mathrm{Na}$, which was explained by the fact that $\mathrm{Na}$ reduces soil pore sizes through increasing the diffuse double layer thickness and creating repulsion forces among clay particles. High concentrations of hydrated $\mathrm{Na}$ and $\mathrm{K}$ cause clay dispersion, resulting in reduced infiltration rate, earlier/increased runoff, and increased sediment concentrations (Auerswald et al., 1996).

Salt-affected soils occur in more than 100 countries of the world, including Iran. The extent and nature of salt problems are diverse (Rengasamy, 2006). Based on estimates of Cheraghi (2004), 50\% of the irrigated area of Iran is affect- ed by different levels of salinity and sodicity. According to a soil database containing information from 10 Iranian provinces covering the most important agricultural areas, the concentration of $\mathrm{K}$ in soil is the highest among macronutrients (Jalali, 2015). The salinisation of land resources in Iran is the consequence of both natural phenomena (geological composition of parent material, stream salinity, wind-borne salinity, seawater intrusion, low rainfall and high evaporation) and anthropogenic activities (irrigation with saline/sodic surface or ground water, inadequate irrigation management practices and drainage facilities, over-grazing of pastures/vegetation) (Qadir et al., 2008). The present study investigated the impact of $\mathrm{K}$ and $\mathrm{Na}$ (with a focus on $\mathrm{K}$ ) on soil structure, its stability and associated properties, and functions, using a loamy soil from north-eastern Iran. The soil was incubated using solutions with different concentrations of $\mathrm{K}$ and $\mathrm{Na}$, and at a range of $\mathrm{K}: \mathrm{Na}$ ratios. Clay dispersion, aggregate stability, the characteristics of the soil pore size distribution and saturated hydraulic conductivity were measured after incubation for one month.

\section{MATERIAL AND METHODS}

Soil samples were collected from the $0-0.3 \mathrm{~m}$ depth of an agricultural field located at the Ferdowsi University of Mashhad, north-eastern Iran $\left(36^{\circ} 18^{\prime} \mathrm{N}\right.$ latitude, 59 $31^{\prime} \mathrm{E}$ longitude and $1030 \mathrm{~m}$ altitude). Basic characteristics of the soil are presented in Table 1. Soil texture was determined using the pipette method (Gee and Bauder, 1986), soil organic carbon was measured using the wet oxidation method (Walkley and Black, 1934), and calcium carbonate was obtained using reverse titration (Sparks et al., 1992). Finally, electrical conductivity (EC) and $\mathrm{pH}$ were determined using the saturated paste extraction method (Richards, 1954). The saturated paste extract was first prepared from the soil. $\mathrm{Ca}$ and $\mathrm{Mg}$ concentrations were then measured using titration by EDTA, and $\mathrm{Na}$ and $\mathrm{K}$ concentrations were determined using a flame photometer apparatus (Richards, 1954). The cation exchange capacity (CEC) $\left(\mathrm{cmol}_{\mathrm{c}} \mathrm{kg}^{-1}\right)$ was determined using the ammonium acetate method (Chapman, 1965), while the cation ratio of soil structural stability (CROSS) was determined as (Rengasamy and Marchuk, 2011):

Table 1. Selected physical and chemical soil properties

\begin{tabular}{|c|c|c|c|c|c|c|c|c|c|c|c|c|c|c|}
\hline Clay & Silt & Sand & $\mathrm{OM}$ & $\mathrm{CaCO}_{3}$ & \multirow{2}{*}{$\begin{array}{l}\mathrm{EC} \\
(\mathrm{dS} \\
\left.\mathrm{m}^{-1}\right)\end{array}$} & \multirow[b]{2}{*}{$\mathrm{pH}$} & $\mathrm{K}$ & $\mathrm{Na}$ & $\mathrm{Ca}$ & $\mathrm{Mg}$ & \multirow[b]{2}{*}{ CROSS } & \multirow{2}{*}{$\begin{array}{l}C E C \\
\mathrm{cmol}_{\mathrm{c}} \\
\mathrm{kg}^{-1}\end{array}$} & \multirow{2}{*}{$\begin{array}{l}\text { Soil } \\
\text { classification } \\
\text { (USDA) }\end{array}$} & \multirow{2}{*}{$\begin{array}{l}\text { Dominant } \\
\text { clay type }\end{array}$} \\
\hline & & $(\%)$ & & & & & \multicolumn{4}{|c|}{$\left(\mathrm{mmol}_{\mathrm{c}} \mathrm{l}^{-1}\right)$} & & & & \\
\hline 20.6 & 47.3 & 32.2 & 1.1 & 15.9 & 1.2 & 7.8 & 0.16 & 3.3 & 5.2 & 3.6 & 1.8 & 10.5 & $\begin{array}{l}\text { Haplo- } \\
\text { cambid }\end{array}$ & $\begin{array}{l}\text { Mica } \\
\text { (muscovite)* }\end{array}$ \\
\hline
\end{tabular}

$\mathrm{OM}$ - organic matter content, EC - electrical conductivity, CROSS - cation ratio of soil structural stability, CEC - cation exchange capacity, *Haghnia (1982). 


$$
\text { CROSS }=\frac{\mathrm{Na}+0.56 \mathrm{~K}}{\sqrt{\frac{\mathrm{Ca}+0.6 \mathrm{Mg}}{2}}},
$$

where the concentrations of cations are in $\operatorname{mmol}_{\mathrm{c}} \mathrm{l}^{-1}$

The soil samples were placed into plastic pots (diameter: $18 \mathrm{~cm}$, height: $22 \mathrm{~cm}$ ) with the bulk density of $1.3 \mathrm{~g} \mathrm{~cm}^{-3}$ (weight: $7 \mathrm{~kg}$ soil) and transferred to the greenhouse, where they were incubated with salt solutions for one month. The following treatments were applied: two levels of electrical conductivity $\left(\mathrm{EC}=3\right.$ and $\left.6 \mathrm{dSm}^{-1}\right)$ and six combinations of $\mathrm{K}$ and $\mathrm{Na}$ concentrations (i.e. six different $\mathrm{K}$ : Na ratios) per EC level, resulting in a total of 12 treatments (Table 2). The range of $\mathrm{K}$ and $\mathrm{Na}$ concentrations were between $0-27.2$ for $\mathrm{EC}=3 \mathrm{dS} \mathrm{m}^{-1}$, and 0-54.4 $\mathrm{mmol}_{\mathrm{c}} \mathrm{l}^{-1}$ for $\mathrm{EC}=6 \mathrm{dS} \mathrm{m}{ }^{-1}$, respectively (Table 2). Constant concentrations of $\mathrm{Ca}$ and $\mathrm{Mg}$ were considered at each EC level because there was no interest in assessing the effect of divalent cations on soil structure. Concentrations of $\mathrm{Ca}$ and $\mathrm{Mg}$ in the treatment solutions were larger than the swelling threshold concentration defined by Quirk and Schofield (1955) (>1 mmol) (Table 2). CROSS was calculated for each treatment solution using Eq. (1), below referred to as ' $C R O S S_{t r}$ '. The solutions were added to the soils using capillary rise from the bottom of pots. Three replicates (i.e. three pots) per treatment were used. The pots were wrapped in plastic bags. The soil in the pots was kept at a water content corresponding to field capacity, and kept for one month in the greenhouse at controlled temperature.

Subsequently, the following measurements on the treated soils were carried out after one month of incubation: the percentage of spontaneous dispersible clay (SDC) as a measure of micro-aggregate stability, water-stable aggregates $(W S A)$ as a measure of macro-aggregate stability, water retention characteristics and pore size distribution parameters (location parameters), relative field capacity $(R F C)$ and air capacity $(A C)$ derived thereof, and saturated hydraulic conductivity $\left(K_{s}\right)$. The methods are described in detail in the following sections. The cationic indicators including $C R O S S$, sodium adsorption ratio $(S A R)$, potassium adsorption ratio $(P A R)$, exchangeable potassium percentage $(E P P)$ and exchangeable sodium percentage $(E S P)$ were calculated from the concentrations of the cations.

The method of Marchuk et al. (2013) was used to measure SDC as a measure of micro-aggregate stability in water (Amezketa, 1999). To this end, $20 \mathrm{~g}$ of soil $(<2 \mathrm{~mm})$ was placed into $250 \mathrm{ml}$ cylinders, and $200 \mathrm{ml}$ of distilled water was added slowly down the sides of the cylinders, taking care to avoid disturbance of the soil. After $12 \mathrm{~h}$, any particles that had dispersed from the soils were gently stirred into suspension and left to stand for $2 \mathrm{~h}$. About $10 \mathrm{ml}$

Table 2. Cation concentrations of the solutions applied to the pots (treatment solutions)

\begin{tabular}{|c|c|c|c|c|c|c|c|c|}
\hline \multirow{2}{*}{$\begin{array}{l}\text { Treatment } \\
\text { No. }\end{array}$} & $\mathrm{K}$ & $\mathrm{Na}$ & $\mathrm{Ca}$ & $\mathrm{Mg}$ & \multirow{2}{*}{$\mathrm{K}: \mathrm{Na}$} & \multirow{2}{*}{$\begin{array}{c}\mathrm{CaCl}_{2+} \mathrm{MgCl}_{2} \\
\left(\mathrm{mmol} \mathrm{l}^{-1}\right)\end{array}$} & \multirow{2}{*}{$\mathrm{EC}\left(\mathrm{dS} \mathrm{m} \mathrm{m}^{-1}\right)$} & \multirow{2}{*}{$\mathrm{CROSS}_{t}$} \\
\hline & \multicolumn{4}{|c|}{$\left(\mathrm{mmol}_{\mathrm{c}} \mathrm{l}^{-1}\right)$} & & & & \\
\hline Control & 0 & 0 & 0 & 0 & 0 & 0 & 0 & 0 \\
\hline $3-\mathrm{t} 1$ & 0.0 & 27.2 & 1.4 & 1.4 & 0 & $0.7+0.7=1.4$ & 3 & 25.7 \\
\hline $3-\mathrm{t} 2$ & 13.6 & 13.6 & 1.4 & 1.4 & 1 & $0.7+0.7=1.4$ & 3 & 20.0 \\
\hline $3-\mathrm{t} 3$ & 21.7 & 5.4 & 1.4 & 1.4 & 4 & $0.7+0.7=1.4$ & 3 & 16.6 \\
\hline $3-t 4$ & 24.7 & 2.5 & 1.4 & 1.4 & 10 & $0.7+0.7=1.4$ & 3 & 15.4 \\
\hline $3-\mathrm{t} 5$ & 26.0 & 1.2 & 1.4 & 1.4 & 22 & $0.7+0.7=1.4$ & 3 & 14.8 \\
\hline $3-\mathrm{t} 6$ & 27.2 & 0.0 & 1.4 & 1.4 & $\infty$ & $0.7+0.7=1.4$ & 3 & 14.4 \\
\hline $6-\mathrm{t} 1$ & 0.0 & 54.4 & 2.8 & 2.8 & 0 & $1.4+1.4=2.8$ & 6 & 36.3 \\
\hline $6-\mathrm{t} 2$ & 27.2 & 27.2 & 2.8 & 2.8 & 1 & $1.4+1.4=2.8$ & 6 & 28.3 \\
\hline $6-\mathrm{t} 3$ & 43.5 & 10.8 & 2.8 & 2.8 & 4 & $1.4+1.4=2.8$ & 6 & 23.5 \\
\hline $6-t 4$ & 49.4 & 4.9 & 2.8 & 2.8 & 10 & $1.4+1.4=2.8$ & 6 & 21.8 \\
\hline $6-\mathrm{t} 5$ & 52.0 & 2.3 & 2.8 & 2.8 & 22 & $1.4+1.4=2.8$ & 6 & 21.0 \\
\hline $6-t 6$ & 54.4 & 0.0 & 2.8 & 2.8 & $\infty$ & $1.4+1.4=2.8$ & 6 & 20.3 \\
\hline
\end{tabular}

EC - electrical conductivity, CROSS ${ }_{t r}$ - cation ratio of soil structural stability of treatment solutions. 
suspension was taken with a pipette from $10 \mathrm{~cm}$ depth $\left(15 \mathrm{~cm}\right.$ cylinder height), dried in the oven at $105^{\circ} \mathrm{C}$ for 24 $\mathrm{h}$, and the amount of dispersible clay in relation to the total amount of clay was determined.

The water soluble cation concentrations $\left(\right.$ mmol $\left._{c} l^{-1}\right)$ were measured on sieved $(<2 \mathrm{~mm})$ treated samples and obtained using a soil:water ratio of 1:2. $\mathrm{Ca}$ and $\mathrm{Mg}$ concentrations were measured using titration by EDTA, and $\mathrm{Na}$ and $\mathrm{K}$ concentrations were determined using a flame photometer apparatus. The amounts of exchangeable cations $\left(\mathrm{cmol}_{\mathrm{c}} \mathrm{kg}^{-1}\right)$ of the samples were determined using the ammonium acetate (1N) method (Richards, 1954). CROSS was calculated from Eq. (1). The sodium adsorption ratio $(S A R)$ was calculated as (Richards, 1954):

$$
S A R=\frac{\mathrm{Na}^{+}}{\sqrt{\frac{\mathrm{Ca}^{2+}+\mathrm{Mg}^{2+}}{2}}} .
$$

The potassium adsorption ratio (PAR) was calculated as (Chen et al., 1983):

$$
P A R=\frac{\mathrm{K}^{+}}{\sqrt{\frac{\mathrm{Ca}^{2+}+\mathrm{Mg}^{2+}}{2}}},
$$

where: the cation concentrations are expressed in $\mathrm{mmol}_{\mathrm{c}}$ $1^{-1}$ in Eqs (2) and (3). The EPP and ESP were calculated as (Richards, 1954):

$$
\begin{aligned}
& E P P=\frac{\mathrm{K}_{e x}}{C E C} 100, \\
& E S P=\frac{\mathrm{Na}_{e x}}{C E C} 100,
\end{aligned}
$$

where $\mathrm{Na}_{e x}$ and $\mathrm{K}_{e x}$ are concentrations of exchangeable cations $\left(\mathrm{cmol}_{\mathrm{c}} \mathrm{kg}^{-1}\right)$ and $C E C$ is the cation exchange capacity, which was determined using the ammonium acetate method (Chapman, 1965).

The percentage of water-stable aggregates (as a measure of macro-aggregate stability) was determined using aggregates of 1-2 $\mathrm{mm}$ in size obtained by means of the wet sieving method. Aggregates of 1-2 $\mathrm{mm}$ in size were obtained from the soil samples using a nest of sieves with a $2 \mathrm{~mm}$ sieve on top and a $1 \mathrm{~mm}$ sieve at the bottom. After this, $12 \mathrm{~g}$ aggregates were placed on a single sieve $(0.25$ $\mathrm{mm}$, mesh number 60 according to ASTM), and the sieve was raised and lowered at 35 cycles per minute for $3 \mathrm{~min}$ over a vertical distance of $1.3 \mathrm{~cm}$ (Kemper and Rosenau, 1986). The percentage of water-stable aggregates was then determined as (Kemper and Rosenau, 1986):

$$
W S A=\frac{A-S}{W-S} 100
$$

where: $A$ is the mass of stable aggregates (g), $S$ is the sand mass ( $\mathrm{g}$ ) on the sieve and $W$ is the sum of aggregate and sand mass (g). Sand mass was measured by dispersing with $2 \mathrm{~g}$ sodium hexamethaphosphate/l, and sieving until only sand particles were left on the sieve (Kemper and Rosenau, 1986).

Soil water retention was measured on soil cores (diameter: $3.5 \mathrm{~cm}$; height: $4 \mathrm{~cm}$ ), subsampled from the pots (one subsample per pot, resulting in 3 replications per treatment) at pressure heads of $0,50,100,300,500$, 1000 and $5000 \mathrm{hPa}$, using pressure plate apparatus. The van Genuchten (1980) function with the Mualem (1976) restriction was fitted to the measured data using the RETC software (van Genuchten et al., 1991):

$$
\theta=\theta_{r}+\left(\theta_{s}-\theta_{r}\right)\left[1+(\alpha h)^{n}\right]^{-m},
$$

where: $\theta_{\mathrm{s}}$ and $\theta_{\mathrm{r}}$ are the saturated and residual water contents $\left(\mathrm{g} \mathrm{g}^{-1}\right)$, respectively, $\alpha$ is a scaling factor $\left(\mathrm{cm}^{-1}\right)$, and $n$ and $m$ are shape parameters.

Pore size distribution functions can be characterised and compared using 'location' parameters, where the location parameters include the mode, median and mean equivalent pore diameter (Reynolds et al., 2009). The soil pore size distribution was obtained indirectly from water retention measurements. Location parameters, including $d_{\text {median }}, d_{\text {mode }}$ and $d_{\text {mean }}$, were calculated using Eqs (8) to (10) (Reynolds et al., 2009):

$$
d_{\text {median }}=\frac{2980 \alpha}{\left(0.5^{-\frac{1}{m}}-1\right)^{\frac{1}{n}}},
$$

where: $\alpha, n$ and $m$ are the parameters of the van Genuchten (1980) equation and 0.5 is the degree of saturation.

$$
d_{\text {mode }}=\frac{2980 \alpha}{\left(\theta_{i}^{-\frac{1}{m}}-1\right)^{\frac{1}{n}}}=\frac{2980 \alpha}{m^{-\frac{1}{n}}},
$$

where: $\theta_{i}$ is the water content at the inflection point of the soil water retention curve (Dexter (2004) for more details), and $d_{\text {mean }}$ is the geometric mean diameter of soil pores:

$$
d_{\text {mean }}=\exp \left(\frac{\operatorname{lnd} \mathrm{nd}_{0.16}+\operatorname{lnd}_{0.5}+\operatorname{lnd}_{0.84}}{3}\right) \text {, }
$$

where: $\mathrm{d}_{0.16}, \mathrm{~d}_{0.5}$, and $\mathrm{d}_{0.84}$ were obtained from Eq. (8) with a degree of saturation equal to $0.16,0.5$ and 0.84 , respectively. The relative field capacity $(R F C)$ and air capacity $(A C)$ were calculated as (Reynolds et al., 2009):

$$
R F C=\frac{\theta_{F C}(h=100 \mathrm{hPa})}{\theta_{S}(h=0 \mathrm{hPa})}, \quad 0 \leq R F C \leq 1,
$$




$$
A C=\theta_{\mathrm{S}}(h=0 \mathrm{hPa})-\theta_{F C}(h=100 \mathrm{hPa}), 0 \leq A C \leq \theta_{S},
$$

where: $\theta_{F C}\left(\mathrm{~m}^{3} \mathrm{~m}^{-3}\right)$ is the water content at field capacity $(100 \mathrm{hPa}), \theta_{S}\left(\mathrm{~m}^{3} \mathrm{~m}^{-3}\right)$ is the saturated water content, and $h$ is the matric suction expressed in $\mathrm{hPa}$.

Hydraulic conductivity $\left(K_{s}\right)$ was measured using the constant head method (Klute and Dirksen, 1986) on soil core samples $(4.5 \mathrm{~cm}$ in diameter and $5 \mathrm{~cm}$ in height) that were subsampled from the pots (one subsample per pot). $K_{s}$ was calculated as:

$$
K_{s}=\frac{Q L}{A t\left(H_{2}-H_{1}\right)},
$$

where: $Q$ is the outlet volume of water flux after reaching steady-state conditions, $L$ is the final height of the soil sample after running the experiment, $A$ is the sample surface area, $t$ is the time, and $\left(H_{2}-H_{1}\right)$ is the difference of the hydraulic head between the inlet and the outlet.

The data were analysed using a general linear model (GLM) for a factorial experiment with a completely randomised design, with three replications per each treatment. Analyses were made with the MINITAB 16 software.
ANOVA were done using the least significant difference (LSD) test (Bonferroni method) at the significance level $\mathrm{p}<0.05$. Linear relationships between parameters were determined using regression analysis.

\section{RESULTS AND DISCUSSION}

Values of SDC for the different treatments were in the range of 0.49 to $1.95 \%$ (Table 3 ). The values for SDC measured in our study have a similar range to that observed by Rengasamy and Marchuk (2011), who studied soils in Australia with textures including sandy loam, loamy sand, clay loam and clay, and found SDC ranging between $0.4 \%$ and $4.2 \%$. The maximum SDC reported by Rengasamy and Marchuk (2011) (4.2\%) was higher than our maximum value of $1.95 \%$ because of the higher clay content of some of their soils (clay loam and clay). The sensitivity to clay dispersion caused by adding monovalent cations is higher in soils with clay contents $>15 \%$ than in soils with lower clay content (Levy and Torrento, 1995), and SDC generally increases with increasing clay content (Levy and Torrento, 1995; Etana et al., 2009). Similarly, in Part II of our series of papers (Farahani et al., 2018), we have found that clay dispersion was higher in a clay soil than in a silty loam soil.

Table 3. Selected properties of the samples after one-month incubation with the treatment solutions

\begin{tabular}{ccccccc}
\hline $\begin{array}{c}\text { Treatment } \\
\text { No. }\end{array}$ & $\begin{array}{c}\text { SDC } \\
(\%)\end{array}$ & $S A R$ & $P A R$ & $E S P$ & $E P P$ & CROSS \\
\hline Control & $0.49 \mathrm{~F}$ & $0.92 \mathrm{~B}$ & $0.09 \mathrm{D}$ & $2.91 \mathrm{C}$ & $3.26 \mathrm{E}$ & $1.04 \mathrm{~B}$ \\
$3-\mathrm{t} 1$ & $0.97 \mathrm{E}$ & $3.13 \mathrm{~A}$ & $0.08 \mathrm{D}$ & $2.84 \mathrm{C}$ & $3.32 \mathrm{E}$ & $3.38 \mathrm{~A}$ \\
$3-\mathrm{t} 2$ & $1.22 \mathrm{D}$ & $2.90 \mathrm{~A}$ & $0.16 \mathrm{C}$ & $2.03 \mathrm{D}$ & $4.08 \mathrm{D}$ & $3.32 \mathrm{~A}$ \\
$3-\mathrm{t} 3$ & $1.42 \mathrm{C}$ & $1.17 \mathrm{~B}$ & $0.26 \mathrm{~B}$ & $3.33 \mathrm{ABC}$ & $5.04 \mathrm{C}$ & $1.50 \mathrm{~B}$ \\
$3-\mathrm{t} 4$ & $1.46 \mathrm{BC}$ & $1.05 \mathrm{~B}$ & $0.26 \mathrm{AB}$ & $3.91 \mathrm{~A}$ & $5.48 \mathrm{AB}$ & $1.34 \mathrm{~B}$ \\
$3-\mathrm{t} 5$ & $1.54 \mathrm{~B}$ & $1.13 \mathrm{~B}$ & $0.32 \mathrm{AB}$ & $3.65 \mathrm{AB}$ & $5.35 \mathrm{~B}$ & $1.41 \mathrm{~B}$ \\
$3-\mathrm{t} 6$ & $1.95 \mathrm{~A}$ & $0.85 \mathrm{~B}$ & $0.32 \mathrm{~A}$ & $3.15 \mathrm{BC}$ & $5.59 \mathrm{~A}$ & $1.19 \mathrm{~B}$ \\
& & & & & \\
Control & $0.49 \mathrm{E}$ & $0.92 \mathrm{D}$ & $0.09 \mathrm{D}$ & $2.91 \mathrm{AB}$ & $3.26 \mathrm{BC}$ & $1.04 \mathrm{D}$ \\
$6-\mathrm{t} 1$ & $0.73 \mathrm{D}$ & $5.96 \mathrm{~A}$ & $0.09 \mathrm{D}$ & $2.22 \mathrm{BC}$ & $2.96 \mathrm{C}$ & $6.52 \mathrm{~A}$ \\
$6-\mathrm{t} 2$ & $0.81 \mathrm{CD}$ & $4.46 \mathrm{~B}$ & $0.37 \mathrm{C}$ & $1.33 \mathrm{C}$ & $5.23 \mathrm{~B}$ & $4.94 \mathrm{~B}$ \\
$6-\mathrm{t} 3$ & $0.81 \mathrm{CD}$ & $2.83 \mathrm{C}$ & $0.65 \mathrm{~B}$ & $1.43 \mathrm{C}$ & $13.63 \mathrm{~A}$ & $3.43 \mathrm{C}$ \\
$6-\mathrm{t} 4$ & $0.97 \mathrm{BC}$ & $1.19 \mathrm{D}$ & $0.63 \mathrm{~B}$ & $3.98 \mathrm{~A}$ & $13.45 \mathrm{~A}$ & $1.69 \mathrm{D}$ \\
$6-\mathrm{t} 5$ & $1.13 \mathrm{~B}$ & $0.86 \mathrm{D}$ & $0.86 \mathrm{~A}$ & $3.70 \mathrm{~A}$ & $12.78 \mathrm{~A}$ & $1.53 \mathrm{D}$ \\
$6-\mathrm{t} 6$ & $1.46 \mathrm{~A}$ & $0.99 \mathrm{D}$ & $0.73 \mathrm{AB}$ & $3.72 \mathrm{~A}$ & $14.62 \mathrm{~A}$ & $1.63 \mathrm{D}$ \\
\hline
\end{tabular}

Mean values of three replicates. SDC - spontaneously dispersible clay, SAR - sodium adsorption ratio, $P A R$ - potassium adsorption ratio, ESP - exchangeable sodium percentage, EPP - exchangeable potassium percentage, CROSS - cation ratio of soil structural stability. The values followed by different letters in the same column are significantly different $(\mathrm{p}<0.05)$. 
As shown in Table 3, SDC was lower at $\mathrm{EC}=6 \mathrm{dS} \mathrm{m}^{-1}$ than at $\mathrm{EC}=3 \mathrm{dS} \mathrm{m}^{-1}$. This could be because of the higher electrolyte concentration at the higher EC level, which reduces deflocculation (dispersion) (Quirk and Schofield, 1955).

A positive significant relationship $(p<0.05)$ was obtained between SDC and K concentration at both EC levels, but no trend was observed between SDC and Na concentration (Fig. 1a). SDC increased significantly $(p<0.05)$ with increasing K:Na ratio (Fig. 1a). The cationic indicators of the different treatments are summarised in Table 3.
No trend was found between SDC and CROSS or SAR (Fig. 1b), but there was a positive significant $(\mathrm{p}<0.05)$ relationship between SDC and PAR at both EC levels (Fig. 1b). $E P P$ and ESP consider the effect of exchangeable $\mathrm{K}$ and $\mathrm{Na}$, respectively (Eqs (4) and (5)). We found positive significant $(\mathrm{p}<0.05)$ relationships between SDC and EPP at both EC levels, but no trend for ESP (Fig. 1c).

Our results indicate a strong effect of $\mathrm{K}$ (both water soluble and exchangeable $\mathrm{K}$ ) on clay dispersion. Our findings are in accordance with Rengasamy and Marchuk (2011), Marchuk and Rengasamy (2012), Marchuk et al.

a

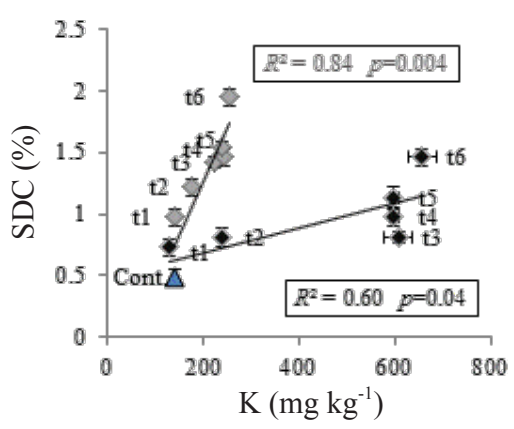

b

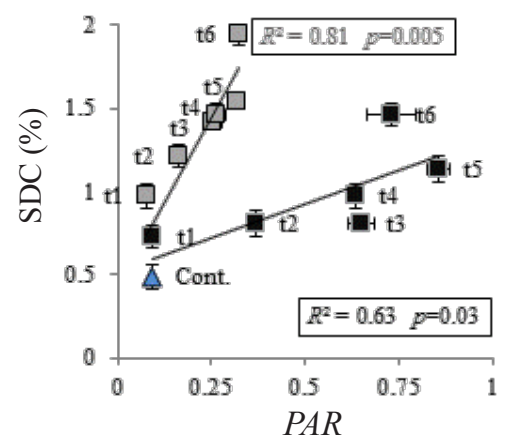

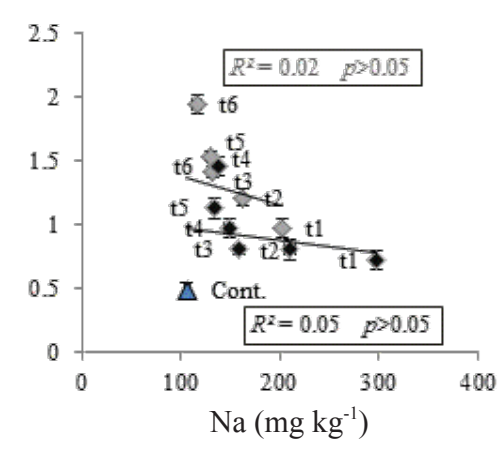

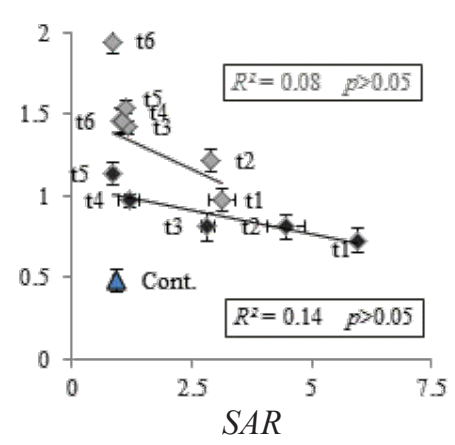

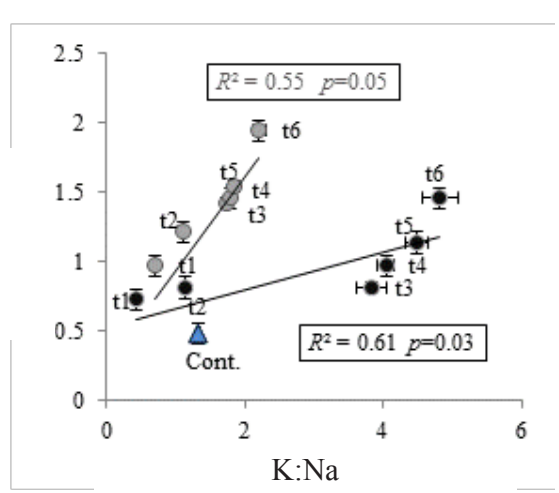

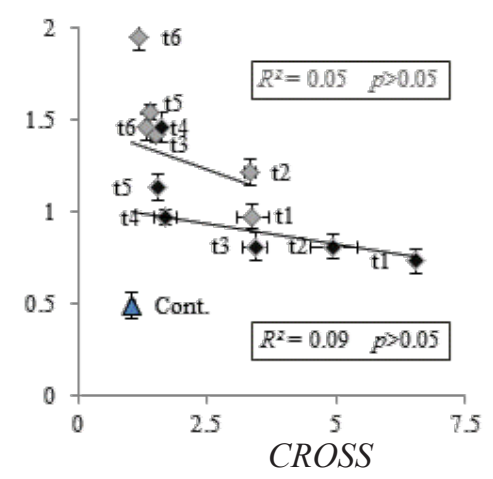

c
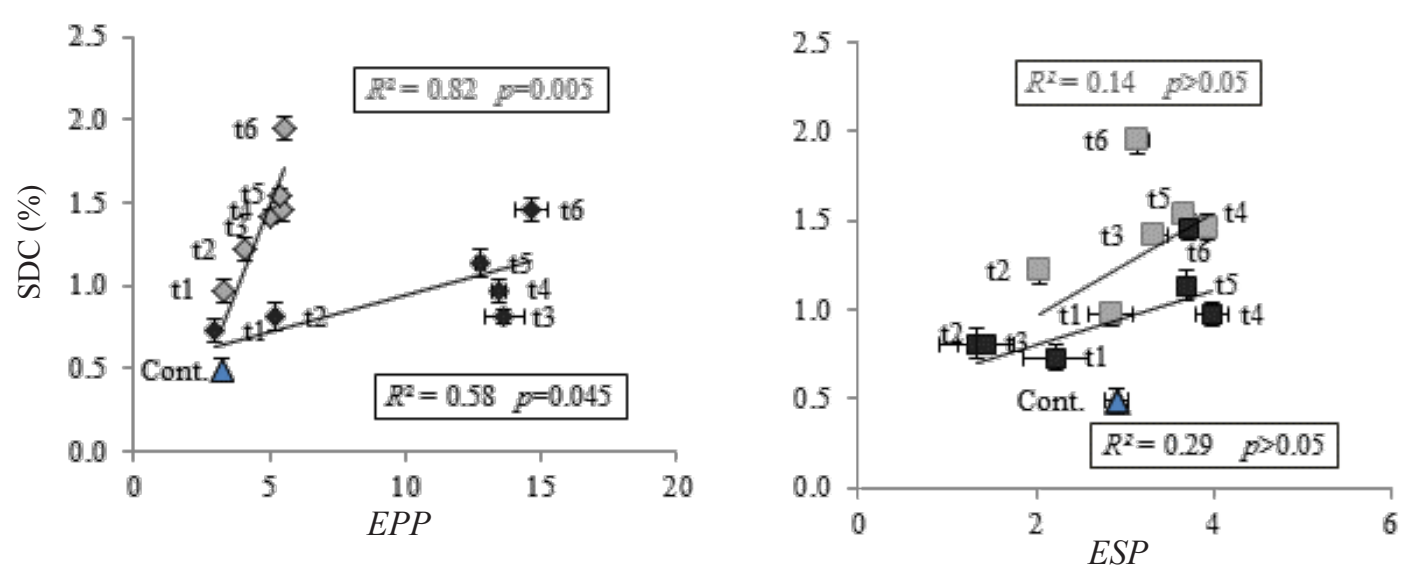

Fig. 1. Percentage of spontaneous dispersible clay (SDC) as a function of: $\mathrm{a}-\mathrm{K}$ concentration, Na concentration and $\mathrm{K}: \mathrm{Na}$ ratio; $\mathrm{b}-$ $P A R, S A R$, and CROSS; and c $-E P P$ and ESP. Grey symbols: $\mathrm{EC}=3 \mathrm{dS} \mathrm{m}{ }^{-1}$; black symbols: $\mathrm{EC}=6 \mathrm{dS} \mathrm{m}^{-1}$; triangle symbol: control. Labels next to the data points indicate treatments (Tables 2 and 3), cont. indicates control. Error bars indicate \pm 1 standard error. 
(2013) and Emami et al. (2014). In contrast, we found no significant effect of $\mathrm{Na}$ on SDC. The role of the amounts of exchangeable $\mathrm{K}(E P P)$ and $\mathrm{Na}(E S P)$ and their dispersive charge/effect in soil are discussed by Rengasamy et al. (2016). EPP and $E S P$ values of the treated samples from our study are presented in Table 3. EPP was higher than ESP in all treated samples, indicating that the higher amounts of exchangeable $\mathrm{K}$ on exchange sites of clay particles led to a stronger dispersive power/charge of $\mathrm{K}$ than of $\mathrm{Na}$, which is consistent with the larger effect of $\mathrm{K}$ on clay dispersion that was observed in the studied soil. Of note, Mancinelli et al. (2007) revealed that water molecules in the hydration shell of $\mathrm{K}$ were more disordered than those hydrating $\mathrm{Na}$. This effect might increase repulsion forces and, hence, generate a K-induced dispersion of clay particles.

The dominant role of $\mathrm{K}$ on clay dispersion implies that $P A R$ and EPP are useful cationic indicators for the soils and treatments used in our study. Because the impact of $\mathrm{Na}$ was small in relation to the impact of K, SAR and ESP were not useful indicators. CROSS, which takes into account the dispersive power of both $\mathrm{Na}$ and $\mathrm{K}$, did not properly reflect the dispersive power of the treatment solutions in our soil, i.e. the relative dispersive power of $\mathrm{Na}$ and $\mathrm{K}$, respectively, was different or had different effects on our soil. The predominant clay mineral in our soil was mica (muscovite) (Table 1), which has a low charge density and usually cannot fix K cations (Arifin et al., 1973), and therefore, K could show its negative effect on soil structure. Moreover, $\mathrm{K}$ ions within the diffuse double layer $(D D L)$ probably increase DDL thickness, facilitating clay dispersion. In contrast, we found a smaller impact of $\mathrm{K}$, compared to $\mathrm{Na}$, on clay dispersion in Swiss soils in Part II of our study (Farahani et al., 2018). The dominant clay type in these soils was illite. Illite has an interlayer K deficiency and, therefore, some of the added $\mathrm{K}$ ions can be adsorbed between the clay layers of illite, i.e. illite can fix K. The role of clay mineralogy on $\mathrm{K}$ effects on soil structure will be discussed in detail in Part II of this series of papers (Farahani et al., 2018).

The relationship between dispersible clay and water-stable aggregates (WSA) is shown in Fig. 2. As can be seen in the figure, the percentage of WSA decreases with increasing clay dispersion. Moreover, negative relationships between WSA and SDC were observed at both EC levels, but the relationship was significant $(\mathrm{p}<0.05)$ only at the lower EC. Molina et al. (2001) also reported significant negative correlations between aggregate stability and dispersible clay. In addition, Amezketa et al. (1996) and Dexter and Czyż (2000) showed that the amount of readily dispersible clay was highly correlated with the aggregate mean weight diameter, which is often used to predict soil erosion. In our soil, the negative relationship between SDC and the percentage of WSA suggests that both macro- and microaggregate stability were negatively affected by potassium. Barzegar et al. (1994) found a strong relationship between aggregate stability and the amount of spontaneously dis-

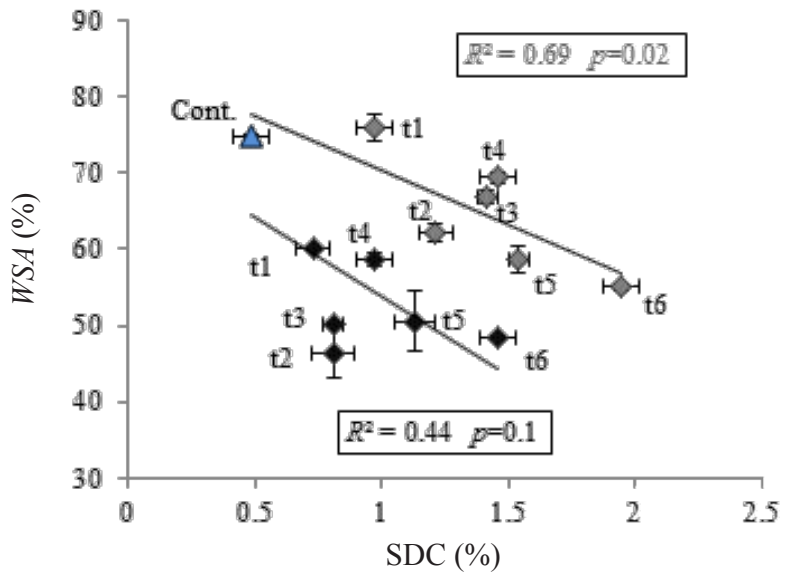

Fig. 2. Aggregate stability (WSA) as a function of the percentage of spontaneous dispersible clay (SDC). Grey symbols: $\mathrm{EC}=3 \mathrm{dS}$ $\mathrm{m}^{-1}$; black symbols: $\mathrm{EC}=6 \mathrm{dS} \mathrm{m} \mathrm{m}^{-1}$; triangle symbol: control. Labels next to the data points indicate treatments (Tables 2 and 3 ), cont. indicates control. Error bars indicate \pm 1 standard error.

persible clay. Similarly, Levy and Torrento (1995) found a significant decrease (about 10\%) in macro-aggregate stability with increasing exchangeable $\mathrm{K}$ concentration (in their study, EPP increased from 2 to $>16.8$ in one soil and from 1.5 to $>13$ in another soil).

Calcium carbonate $\left(\mathrm{CaCO}_{3}\right)$ is known to increase aggregate stability due to its flocculating effects. Our soil had a high $\mathrm{CaCO}_{3}$ concentration and a high $\mathrm{pH}$ (Table 1). We found no differences in $\mathrm{pH}$ between the treated and control soils after incubation, as the $\mathrm{pH}$ after incubation was $>8$ in all samples (not shown). If the soil is alkaline with $\mathrm{pH}>8$, solubility of $\mathrm{CaCO}_{3}$ is insignificant (Chorom and Rengasamy, 1997). Therefore, we conjecture that $\mathrm{CaCO}_{3}$ did not dissolve in the treated samples, and that $\mathrm{CaCO}_{3}$ did have similar effects in all treatments. That is, differences between treatments were not caused by $\mathrm{CaCO}_{3}$.

The location parameters of the pore size distribution $\left(d_{\text {mean }}, d_{\text {median }}\right.$ and $\left.d_{\text {mode }}\right)$, the relative field capacity $(R F C)$, and the air capacity $(A C)$ of the treated soils are shown in Table 4. At EC $=3 \mathrm{dS} \mathrm{m}^{-1}$, the treatment containing the highest $\mathrm{K}$ concentration and the highest $\mathrm{K}: \mathrm{Na}$ ratio (treatment t6; Table 2) had the lowest $d_{\text {mean }}, d_{\text {median }}$ and $d_{\text {mode }}$, the lowest $A C$, and the highest $R F C$. These data support the results presented in previous sections that show a negative effect of $\mathrm{K}$ on soil structure.

At the lower EC level, soil pores became smaller with increasing $\mathrm{K}$ concentration (especially for treatments t4 to t6), which increased $R F C$ (significantly) and reduced $A C$ (non-significant). As shown earlier, increasing $\mathrm{K}$ concentration increased clay dispersion (Fig. 1), which probably engendered the migration of dispersed clay particles into soil pores, resulting in a reduction of the average pore size and, consequently, a decrease in $d_{\text {mean }}, d_{\text {median }}$ and $d_{\text {mode }}$, a decrease in $A C$ and an increase in $R F C$ (Table 4). Clay particle rearrangement following aggregate destruction and 
Table 4. Soil pore size distribution parameters, relative field capacity $(R F C)$ and air capacity $(A C)$ of the incubated soils

\begin{tabular}{|c|c|c|c|c|c|}
\hline \multirow{2}{*}{$\begin{array}{l}\text { Treatment } \\
\text { No. }\end{array}$} & $d_{\text {median }}$ & $d_{\text {mode }}$ & $d_{\text {mean }}$ & \multirow{2}{*}{$R F C$} & \multirow{2}{*}{$A C$} \\
\hline & \multicolumn{3}{|c|}{$\mu \mathrm{m}$} & & \\
\hline Control & $31 \mathrm{BC}$ & $43 \mathrm{~B}$ & $26 \mathrm{AB}$ & $0.664 \mathrm{AB}$ & $0.204 \mathrm{~A}$ \\
\hline $3-\mathrm{t} 1$ & $43 \mathrm{AB}$ & $58 \mathrm{AB}$ & $37 \mathrm{~A}$ & $0.581 \mathrm{~B}$ & $0.281 \mathrm{~A}$ \\
\hline $3-\mathrm{t} 2$ & $30 \mathrm{C}$ & $41 \mathrm{~B}$ & $25 \mathrm{AB}$ & $0.649 \mathrm{AB}$ & $0.237 \mathrm{~A}$ \\
\hline $3-\mathrm{t} 3$ & $48 \mathrm{~A}$ & $80 \mathrm{~A}$ & $33 \mathrm{AB}$ & $0.608 \mathrm{AB}$ & $0.265 \mathrm{~A}$ \\
\hline $3-t 4$ & $39 \mathrm{ABC}$ & $53 \mathrm{AB}$ & $30 \mathrm{AB}$ & $0.618 \mathrm{AB}$ & $0.249 \mathrm{~A}$ \\
\hline $3-\mathrm{t} 5$ & $36 \mathrm{ABC}$ & $52 \mathrm{AB}$ & $30 \mathrm{AB}$ & $0.647 \mathrm{AB}$ & $0.215 \mathrm{~A}$ \\
\hline $3-\mathrm{t} 6$ & $17 \mathrm{D}$ & $36 \mathrm{~B}$ & $17 \mathrm{~B}$ & $0.701 \mathrm{~A}$ & $0.197 \mathrm{~A}$ \\
\hline Control & $31 \mathrm{~A}$ & $43 \mathrm{~A}$ & $26 \mathrm{~B}$ & $0.664 \mathrm{~A}$ & $0.204 \mathrm{~A}$ \\
\hline $6-\mathrm{t} 1$ & $39 \mathrm{~A}$ & $52 \mathrm{~A}$ & $34 \mathrm{AB}$ & $0.616 \mathrm{~A}$ & $0.257 \mathrm{~A}$ \\
\hline $6-\mathrm{t} 2$ & $35 \mathrm{~A}$ & $52 \mathrm{~A}$ & $29 \mathrm{AB}$ & 0.619A & $0.231 \mathrm{~A}$ \\
\hline $6-\mathrm{t} 3$ & $35 \mathrm{~A}$ & $43 \mathrm{~A}$ & $36 \mathrm{~A}$ & $0.632 \mathrm{~A}$ & $0.225 \mathrm{~A}$ \\
\hline $6-\mathrm{t} 4$ & $35 \mathrm{~A}$ & $50 \mathrm{~A}$ & $30 \mathrm{AB}$ & $0.648 \mathrm{~A}$ & $0.211 \mathrm{~A}$ \\
\hline $6-\mathrm{t} 5$ & $38 \mathrm{~A}$ & $55 \mathrm{~A}$ & $33 \mathrm{AB}$ & $0.611 \mathrm{~A}$ & $0.279 \mathrm{~A}$ \\
\hline $6-t 6$ & $32 \mathrm{~A}$ & $44 \mathrm{~A}$ & $28 \mathrm{~B}$ & $0.651 \mathrm{~A}$ & $0.222 \mathrm{~A}$ \\
\hline
\end{tabular}

Mean values of three replicates. The values followed by different letters in the same column are significantly different $(\mathrm{p}<0.05)$.

the resulting pore size reduction is referred to as 'shortrange migration' (Chen and Banin, 1975). Marchuk et al. (2012) applied X-ray computed tomography to characterise changes in the pore system of a sandy loam as influenced by exchangeable cations. They found a well-developed pore structure in soils with high concentration of divalent cations ( $\mathrm{Ca}$ and $\mathrm{Mg}$ ), while soils dominated by monovalent cations $(\mathrm{Na}$ and $\mathrm{K}$ ) mostly included non-connected pores and pores filled with dispersed clay particles. At $\mathrm{EC}=6 \mathrm{dS}$ $\mathrm{m}^{-1}$, differences between treatments were not significant (Table 4). The reason for the non-significant differences between treatments might be related to the lower SDC at $\mathrm{EC}=6 \mathrm{dS} \mathrm{m}^{-1}$ (Table 3), as discussed above.

The parameters of the van Genuchten (1980) equation $\left(\theta_{s}, \theta_{r}, \alpha\right.$, and $n$; Eq. (7)), together with the water contents at field capacity (i.e. at matric suction of $100 \mathrm{hPa} ; \theta_{F C}$ ) and at the inflection point of the water retention curve $\left(\theta_{i}\right)$ at both EC levels are shown in Table 5. Although the differences were not statistically significant, incubation with treatment solutions increased water retention compared with the control, and the highest water contents were measured for the treatment with the highest $\mathrm{K}$ concentration and the largest $\mathrm{K}: \mathrm{Na}$ ratio (treatment $\mathrm{t6}$, Table 2). These results indicate that clay dispersion induced the clogging of soil pores, resulting in a general decrease in pore size and an associated increase in water retention.
Figure 3 shows the saturated hydraulic conductivity $\left(K_{s}\right)$ as a function of $E P P$. We observed an increase in $K_{s}$ with increasing $E P P$ at low $E P P$ at both EC levels, as indicated in Fig. 3. However, at higher $E P P, K_{s}$ decreased with further increase in $E P P$ (Fig. 3). The decrease in $K_{s}$ at high $\mathrm{K}$ concentrations was most likely caused by the pore size reduction due to pore clogging by dispersed clay particles, as discussed above. Of note, Ben-Hur et al. (2009) found that the plugging of soil pores with dispersed clay particles reduced $K_{s}$ in a clay soil. Furthermore, a network of dispersed clay particles filling the pore spaces between larger particles was observed by Chen et al. (1983) using scanning electron micrographs, which showed that enrichment with $\mathrm{K}$ resulted in the plugging of pores, causing a reduction in water infiltration and soil hydraulic conductivity. There was no correlation between $K_{s}$ and $E S P$ at either EC level.

Similarly to our results, Chen et al. (1983) found for two soils (a loamy sand and a heavy clay soil) that $K_{s}$ increased up to a certain value of $E P P$ and then sharply decreased with further increase in EPP. According to them, underlying this was the interlayer adsorption of $\mathrm{K}$ on clay surfaces at low EPP resulting in the stabilisation of micro aggregates (Auerswald et al., 1996), and clay dispersion resulting in structure destabilisation at large EPP (Chen et al., 1983). The latter is consistent with the findings of several researchers who have reported that clay dispersion 
Table 5. Parameters of the van Genuchten (1980) function $\left(\theta_{s}, \theta_{p}, \alpha\right.$, and $n$; Eq. (7)) that was fitted to the water retention data, and water contents at field capacity (i.e. at a matric suction of $\left.100 \mathrm{hPa} ; \theta_{F C}\right)$ and at the inflection point of the water retention curve $\left(\theta_{i}\right)$. $\theta_{s}-$ saturated water content; $\theta_{r}$ - residual water content; $\alpha$ and $n$ are fitting parameters

\begin{tabular}{ccccccc}
\hline \multirow{2}{*}{$\begin{array}{c}\text { Treatment } \\
\text { No. }\end{array}$} & $\theta_{s}$ & $\theta_{i}$ & $\theta_{F C}$ & $\theta_{r}$ & $\alpha$ & $n$ \\
\cline { 2 - 6 } Control & \multicolumn{2}{c}{$\mathrm{cm}^{3} \mathrm{~cm}^{-3}$} & & $\mathrm{hPa}^{-1}$ & $(-)$ \\
\hline $3-\mathrm{t} 1$ & $0.606 \mathrm{~A}$ & $0.445 \mathrm{~A}$ & $0.402 \mathrm{~A}$ & $0.203 \mathrm{~A}$ & $0.0235 \mathrm{~A}$ & $1.733 \mathrm{~A}$ \\
$3-\mathrm{t} 2$ & $0.671 \mathrm{~A}$ & $0.483 \mathrm{~A}$ & $0.390 \mathrm{~A}$ & $0.206 \mathrm{~A}$ & $0.0313 \mathrm{~A}$ & $1.768 \mathrm{~A}$ \\
$3-\mathrm{t} 3$ & $0.676 \mathrm{~A}$ & $0.486 \mathrm{~A}$ & $0.439 \mathrm{~A}$ & $0.201 \mathrm{~A}$ & $0.0226 \mathrm{~A}$ & $1.745 \mathrm{~A}$ \\
$3-\mathrm{t} 4$ & $0.673 \mathrm{~A}$ & $0.494 \mathrm{~A}$ & $0.408 \mathrm{~A}$ & $0.206 \mathrm{~A}$ & $0.0436 \mathrm{~A}$ & $1.614 \mathrm{~A}$ \\
$3-\mathrm{t} 5$ & $0.655 \mathrm{~A}$ & $0.474 \mathrm{~A}$ & $0.406 \mathrm{~A}$ & $0.190 \mathrm{~A}$ & $0.0317 \mathrm{~A}$ & $1.640 \mathrm{~A}$ \\
$3-\mathrm{t} 6$ & $0.607 \mathrm{~A}$ & $0.451 \mathrm{~A}$ & $0.392 \mathrm{~A}$ & $0.183 \mathrm{~A}$ & $0.0304 \mathrm{~A}$ & $1.725 \mathrm{~A}$ \\
$6-\mathrm{t} 1$ & $0.657 \mathrm{~A}$ & $0.480 \mathrm{~A}$ & $0.461 \mathrm{~A}$ & $0.215 \mathrm{~A}$ & $0.0247 \mathrm{~A}$ & $1.547 \mathrm{~A}$ \\
$6-\mathrm{t} 2$ & $0.667 \mathrm{~A}$ & $0.445 \mathrm{~A}$ & $0.402 \mathrm{~A}$ & $0.224 \mathrm{~A}$ & $0.0281 \mathrm{~A}$ & $1.791 \mathrm{~A}$ \\
$6-\mathrm{t} 3$ & $0.606 \mathrm{~A}$ & $0.487 \mathrm{~A}$ & $0.410 \mathrm{~A}$ & $0.201 \mathrm{~A}$ & $0.0283 \mathrm{~A}$ & $1.762 \mathrm{~A}$ \\
$6-\mathrm{t} 4$ & $0.611 \mathrm{~A}$ & $0.443 \mathrm{~A}$ & $0.374 \mathrm{~A}$ & $0.190 \mathrm{~A}$ & $0.0345 \mathrm{~A}$ & $1.673 \mathrm{~A}$ \\
$6-\mathrm{t} 5$ & $0.599 \mathrm{~A}$ & $0.448 \mathrm{~A}$ & $0.386 \mathrm{~A}$ & $0.211 \mathrm{~A}$ & $0.0284 \mathrm{~A}$ & $1.702 \mathrm{~A}$ \\
$6-\mathrm{t} 6$ & $0.709 \mathrm{~A}$ & $0.445 \mathrm{~A}$ & $0.388 \mathrm{~A}$ & $0.214 \mathrm{~A}$ & $0.0323 \mathrm{~A}$ & $1.661 \mathrm{~A}$ \\
\hline
\end{tabular}

Mean values of three replicates. The values followed by different letters in the same column are significantly different $(\mathrm{p}<0.05)$.

a

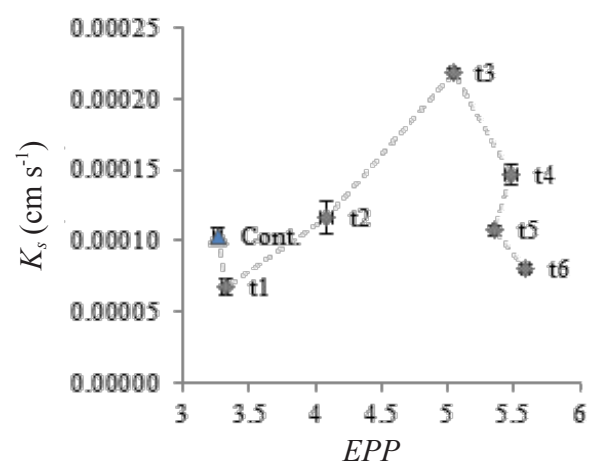

b

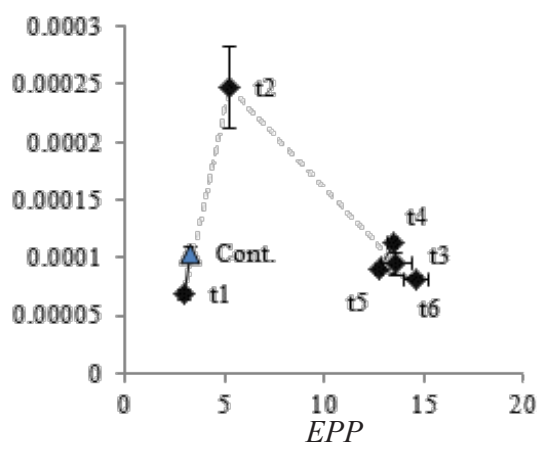

Fig. 3. Saturated hydraulic conductivity $\left(K_{s}\right)$ as a function of exchangeable potassium percentage $(E P P)$. Grey symbols: a $-E C=$ $3 \mathrm{dS} \mathrm{m}^{-1}$; black symbols: $\mathrm{b}-\mathrm{EC}=6 \mathrm{dS} \mathrm{m} \mathrm{m}^{-1}$; triangle symbol: control. Labels next to the data points indicate treatments (Tables 2 and 3), cont. indicates control. Error bars indicate \pm 1 standard error.

results in a reduction in $K_{s}$ (Levy et al., 1998; Keren and Ben-Hur, 2003). However, we found increasing SDC within increasing EEP at all EPP levels (Fig. 1b), and, hence, the explanation by Chen et al. (1983) is not supported by our data. We suggest that further studies are required to clarify the effect of $\mathrm{K}$ on $K_{s}$ at different $E P P$ levels. In addition to $\mathrm{K}$ concentration, the effect of $\mathrm{K}$ on soil structure is also affected by clay mineralogy, and this will be discussed in Part II of this series of papers (Farahani et al., 2018).

\section{CONCLUSIONS}

1. Clay dispersion, measured in the form of spontaneously dispersible clay, increased with increasing $\mathrm{K}$ concentration and increasing $\mathrm{K}: \mathrm{Na}$ ratio, and, therefore, with increasing potassium adsorption ratio, and with increasing exchangeable potassium percentage. This result reveals that potassium adsorption ratio and exchangeable potassium percentage are good indicators for evaluating the adverse effect of $\mathrm{K}$ on the structure of the studied soil. 
In contrast, no relation between spontaneously dispersible clay and $\mathrm{Na}$ was found for our soil and experimental conditions.

2. The percentage of water stable aggregates decreased with increasing spontaneously dispersible clay, and this negative relationship shows that aggregate stability was negatively affected by $\mathrm{K}$.

3. Mean soil pore size decreased and water retention increased with increasing spontaneously dispersible clay, which probably can be attributed to the short-range migration of clay, i.e. the clogging of soil pores by dispersed clay.

4. Saturated hydraulic conductivity increased with increasing exchangeable potassium percentage at low exchangeable potassium percentage levels but decreased with increasing exchangeable potassium percentage at high exchangeable potassium percentage levels. Further studies are needed to understand the mechanisms resulting in this behaviour.

The results obtained demonstrate that potassium can have negative impacts on soil structure. Further studies are needed to improve our understanding of $\mathrm{K}$ impacts on soil structure as affected by $\mathrm{K}$ concentration, clay content and clay mineralogy.

\section{ACKNOWLEDGEMENTS}

Appreciation is expressed to the Ferdowsi University of Mashhad for the financial support of this research.

Conflict of interest: The Authors do not declare conflict of interest.

\section{REFERENCES}

Amezketa E., 1999. Soil Aggregate Stability: A Review. J. Sustainable Agric., 14: 2-3, 83-151.

Amezketa E., Singer M.J., and Le Bissonnais Y., 1996. Testing a new procedure for measuring water-stable aggregation. Soil Sci. Soc. Am. J., 60, 888-894.

Arienzo M., Christen E.W., Quayle W., and Kumar A., 2009. A review of the fate of potassium in the soil-plant system after land application of wastewaters. J. Hazardous Materials, 164, 415-422.

Arifin R.B., Perkins H.F., and Tau K.H., 1973. Potassium fixation and reconstitution of micaceous structures in soils. Soil Sci., 116, 31-35.

Arshad M.A. and Coen G.M., 1992. Characterization of soil quality: Physical and chemical criteria. Am. J. Altern. Agric., 7, 25-32.

Auerswald K., Kainz M., Angermuller S., and Steindl H., 1996. Influence of exchangeable potassium on soil erodibility. Soil Use and Management, 12, 117-121.

Barzegar A.R., Oades J.M., Rengasamy P., and Giles L., 1994. Effect of sodicity and salinity on disaggregation and tensile strength of an Alfisol under different cropping systems. Soil Till. Res., 32, 329-345.

Ben-Hur M., Yolcu G., Uysal H., Lado M., and Paz A., 2009.
Soil structure changes: aggregate size and soil texture effects on hydraulic conductivity under different saline and sodic conditions. Soil Res., 47(7), 688-696.

Chapman H.D., 1965. Cation exchange capacity. In: Methods of Soil Analysis part 2 (Eds C.A. Black), 891-901. Number 9 in the series Agronomy: Am. Inst. Agronomy, Madison, WI, USA.

Chaudhari S.K. and Somawanshi R.B., 2004. Unsaturated flow of different quality irrigation waters through clay, clay loam and silt loam soils and its dependence on soil and solution parameters. Agric. Water Manag., 64, 69-90.

Chen Y. and Banin A., 1975. Scanning electron microscope (SEM) observation of soil structure changes induced by Sodium-Calcium exchange in relation to hydraulic conductivity. Soil Sci., 120,428-436.

Chen Y., Banin A., and Borochovitch A., 1983. Effect of potassium on soil structure in relation to hydraulic conductivity. Geoderma, 30,135-147.

Cheraghi S.A.M., 2004. Institutional and scientific profiles of organizations working on saline agriculture in Iran. In: Prospects of saline agriculture in the Arabian Peninsula: Proc. Int. Seminar Prospects of saline agriculture in the GCC Countries (Eds F.K. Taha, S. Ismail, A. and Jaradat), March 18-20, 2001, Dubai, United Arab Emirates, Amherst, MA: Amherst Scientific Publishers.

Chorom M. and Rengasamy P., 1997. Carbonate chemistry, $\mathrm{pH}$, and physical properties of an alkaline sodic soil as affected by various amendments. Soil Res., 35, 149-162.

Dexter A.R., 2004. Soil physical quality. Part I: Theory, effects of soil texture, density and organic matter, and effects on root growth. Geoderma, 120, 201-214.

Dexter A.R. and Czyż E.A., 2000. Effects of soil management on the dispersibility of clay in a sandy soil. Int. Agrophysics, 14, 269-272.

Emami H., Astaraei A.R., Fotovat A., and Khotabaei M., 2014. Effect of soil conditions on cation ratio on soil structural stability, structural stability indicators in a sodic soil, and on dry weight of maize. Arid Land Res. Manag., 28, 325-339.

Etana A., Rydberg T., and Arvidsson J., 2009. Readily dispersible clay and particle transport in five Swedish soils under long-term shallow tillage and mouldboard ploughing. Soil Tillage Res., 106, 79-84.

Farahani E., Emami H., and Keller T., 2018. Impact of monovalent cations on soil structure. Part II. Results of two Swiss soils. Int. Agrophysics, 32, 69-80.

Gee G.W., and Bauder J.W., 1986. Particle-size distribution. In: Methods of Soil Analysis. Part 1. Physical and Mineralogical Methods (Eds A. Klute). Agron. Monog., 9. ASA/SSSA, Madison, WI, 384-411.

Jalali V.R., 2015. Final report of creation of web Iranian soil data base, proper tool to evaluate soil properties in national scale (soil data management, first phase: 10 provinces). ACECR, Tehran.

Kay B.D., 1990. Rates of change of soil structure under different cropping systems. Advances Soil Sci., 12, 1-52.

Kemper W.D. and Rosenau R.C., 1986. Aggregate stability and size distribution. In: Methods of soil analysis. Part 1. Physical and mineralogical methods (Eds A. Klute). Agron. Monogr. 9. ASA and SSSA, Madison, WI, 425-442.

Keren R. and Ben-Hur M., 2003. Interaction effects of clay 
swelling and dispersion and $\mathrm{CaCO}_{3}$ content on saturated hydraulic conductivity. Australian J. Soil Res., 41, 979-989.

Khan G.S. and Afzal T., 1990. Hydraulic characteristics of some important soil levels of Pakistan. In: Soil PhysicsApplication under Stress Environment. Pakistan Agric. Res. Council, Islamabad, 224-237.

Klute A. and Dirksen C., 1986. Hydraulic conductivity and diffusivity. In: Methods of Soil Analysis (Eds A. Klute). ASA Press, Madison, WI, USA.

Levy G.J., Shainberg I., and Miller P., 1998. Physical properties of sodic soils. In: Sodic soils: Distribution, Properties, Management, and Environmental Consequences (Eds M.E. Sumner, R. Naidu). Oxford University Press, New York, USA.

Levy G.J. and Torrento J.R., 1995. Clay dispersion and macroaggregate stability as affected by exchangeable potassium and sodium. Soil Sci., 160, 352-358.

Mancinelli R., Botti A., Bruni F., Ricci M.A., and Soper A.K., 2007. Hydration of sodium, potassium, and chloride ions in solution and the concept of structure maker/breaker. The J. Physical Chemistry B, 111(48), 13570-13577.

Marchuk A. and Rengasamy P., 2012. Threshold electrolyte concentration and dispersive potential in relation to CROSS in dispersive soils. Soil Res., 50, 473-481.

Marchuk A., Rengasamy P., and McNeill A., 2013. Influence of organic matter, clay mineralogy and $\mathrm{pH}$ on the effects of CROSS on soil structure is related to the zeta potential of the dispersed clay. Soil Res., 51, 34-40.

Marchuk A., Rengasamy P., McNeill A., and Kumar A., 2012. Nature of the clay-cation bond affects soil structure as verified by X-ray computed tomography. Soil Res., 50, 638-644.

Molina N.C., Caceres M.R., and Pietroboni A.M., 2001. Factors affecting aggregate stability and water dispersible clay of recently cultivated semiarid soils of Argentina. Arid Land Res. Manag., 15(1), 77-87.

Mualem Y., 1976. A new model for predicting the hydraulic conductivity of unsaturated porous media. Water Resour. Res., 12, 513-522.

Pieri C.J.M.G., 1992. Fertility of Soils: A Future for Farming in the West African Savannah. Springer-Verlag, Berlin, Germany.

Qadir M., Qureshi A.S., and Cheraghi S.A.M., 2008. Extent and characterisation of salt-affected soils in Iran and strategies for their amelioration and management. Land Degradation Develop., 19(2), 214-227.
Quirk J.P. and Schofield R.K., 1955. The effect of electrolyte concentration on soil permeability. J. Soil Sci., 6, 163-178.

Rengasamy P., 2002. Clay dispersion. In: Soil physical measurement and interpretation for land evaluation. (Eds B.M. McKenzie et al.). CSIRO Publishing, Melbourne, Australia.

Rengasamy P., 2006. World salinization with emphasis on Australia. J. Exp. Botany, 57, 1017-1023.

Rengasamy P. and Marchuk A., 2011. Cation ratio of soil structural stability (CROSS). Soil Res., 49, 280-285.

Rengasamy P., Tavakoli E., and McDonald G.K., 2016. Exchangeable cations and clay dispersion: net dispersive charge, a new concept for dispersive soil. Eur. J. Soil Sci., 67, 659-665.

Reynolds W.D., Drury C.F., Tan C.S., Fox C.A., and Yang X.M., 2009. Use of indicators and pore volume-function characteristics to quantify soil physical quality. Geoderma, 152, 252-263.

Richards L.A., 1954. Diagnosis and Improvement of Saline and Alkali Soils. USDA Hand book, Washington, USA.

Shainberg I. and Letey J., 1984. Response of soils to sodic and saline conditions. Hilgardia, 52(2), 1-57.

Six J., Bossuyt H., Degryze S., and Denef K., 2004. A history of research on the link between (micro) aggregates, soil biota, and soil organic matter dynamics. Soil Till. Res., 79, 7-31.

Smiles D.E., 2006. Sodium and potassium in soils of the MurrayDarling Basin: a note. Australian J. Soil Res., 44, 727-730.

Sparks D.L., Fendorf S.E., Zhang P.C., and Tang L., 1992. Kinetics and mechanisms of environmentally important reactions on soil colloidal surface. NATO Advanced Study Institute on Migration and Fate of Pollutants in Soils and Subsoils, May 24-June 5, Maratea, Italy.

Sumner M.E., 1993. Sodic soils: New perspectives. Aust. J. Soil Res., 31, 683-750.

van Genuchten M.Th., 1980. A closed-form equation for predicting the hydraulic conductivity of unsaturated soils. Soil Sci. Soc. Am. J., 44, 892-898.

van Genuchten M.V., Leij F.J., and Yates S.R., 1991. The RETC code for quantifying the hydraulic functions of unsaturated soils. U.S. Salinity Laboratory U.S. Department of Agriculture, Agricultural Research Service, Riverside, CI, USA.

Walkley A. and Black I.A., 1934. An Examination of Degtjareff method for determining soil organic matter and a proposed modification of the chromic acid titration method. Soil Sci., 37, 29-37. 